\title{
CONTEMPORARY TRAINING IN FINANCIAL ACCOUNTING - SYNTHESIS BETWEEN TRADITIONAL METHODS AND NEW DIGITAL INSTRUMENTS
}

\author{
Atanas Atanasov ${ }^{1}$, Galina Chipriyanova ${ }^{2 \star}$, Radosveta Krasteva-Hristova ${ }^{3}$, Kiril \\ Luchkov ${ }^{4}$ \\ ${ }^{1}$ Prof. Dr., D.A. Tsenov Academy of Economics, Bulgaria, a.atanasov@uni-svishtov.bg \\ ${ }^{2}$ Assoc. Prof. Dr., D.A. Tsenov Academy of Economics, Bulgaria, g.chipriyanova@uni-svishtov.bg \\ ${ }^{3}$ Asst. Prof. Dr., D.A. Tsenov Academy of Economics, Bulgaria, r.krasteva@uni-svishtov.bg \\ ${ }^{4}$ Student Dr. Kiril Luchkov, D.A. Tsenov Academy of Economics, Bulgaria, kiril.luckov@gmail.com \\ ${ }^{*}$ Corresponding author
}

\begin{abstract}
The practice has proved that financial accounting is the language of business and the main reporting and information system designed to record and perform current processing of reporting data on business and financial transactions, and periodically present information about the property and financial condition of the enterprise. In the digital economy, the business is constantly changing, the number of electronic administrative and public services is increasing, new types of transactions and new ways of payment between counterparties from EU member states and beyond appear, new means of payment (virtual money), lifelong learning, etc. New objects of accounting are changing and / or appearing, which in parallel with the dynamic parameters of the business naturally require a change in the methods and organization of training in financial accounting, timely updates of the curriculum and syllabus and others.
\end{abstract}

The training in the discipline "Financial Accounting" in the universities of the European Education Area is key for students in the professional fields of "Economics" and "Administration and Management". It helps to build the basis for their further professional development, dictated by the following circumstances: accounting competence is a prerequisite for effective and efficient performance of professional duties; knowledge of financial accounting is a solid information base for making economic decisions; future professionals are taught that their actions must be based on relevant, essential, reliable and comparable data, which is best provided by financial accounting; future professionals are motivated to value accounting information as one of the most important resources, along with finance, investment and innovation; and future specialists are educated for the rational use of accounting information as a prerequisite and criterion for improving the work.

It is a fact that in the last 1-2 years there have been some difficulties with the wide access of students to universal learning resources in view of the pandemic of COVID-19. The present study aims to analyze the digitalization of financial accounting education in universities as a process based on meaningful learning activities that take place in an interactive environment and to reveal the extent of this digitalization at the moment and in the near future.

The analysis is based on a static study - the sample was formed on the basis of the universities presented in the QS World University Rankings for 2021, Europe region, subject Accounting and Finance, Bachelor's degree. Statistical tools and analysis are attached. The results of the research are expressed in the description and analysis of the organization of the educational process in financial accounting in the best selected universities, the development of classification of teaching methods of traditional and innovative, disclosure of good practices in applying new digital tools. A dynamic aspect of the research was also performed. The sample was formed by universities in Europe with a Department of Economics, which study the discipline of "Financial Accounting" by the method of random non-recurrent selection, respectively, 
Bulgaria, Romania, Serbia, Italy, Poland, Croatia, Lithuania, Slovakia. The methodology of structured interview was used. The results of the research are expressed in establishing the trend for digitalization of financial accounting education in universities, tracking the change in the ratio of traditional methods to innovative methods in the course of the educational process in recent years. The study focuses on determining internal factors for the success of this process, such as the presence of strong leadership, defined strategic goals of digitalization, creating new working models and finding effective digital tools.

In conclusion, the application of digital technologies in the process of training in financial accounting in the Bachelor's degree is important for ensuring accessibility, timeliness and management of educational resources as a basis for quality education. It is planned to provide universal electronic access to the implemented platform for educational services and content for the users in the educational process. The study reveals the importance of organizing the training process in financial accounting based on reasonable (optimal) proportions between traditional methods and innovative methods (digital tools) for the acquisition of lasting knowledge, skills and competences for business.

Keywords: financial accounting, training, Bachelor's degree, digitalization, digital tools

\section{INTRODUCTION}

The accounting is a human economic activity and is a scientifically developed system for consistent, continuous, complete, documented and interconnected recording of the activities of each operating enterprise in value and has got a specific methodology for providing the necessary reporting information for the effective management.

For that reason, the accounting is considered to be a expedient human activity and as a serious scientific field. Since the accounting is an occupation (job), it is a reality and the people are able to become aware of that reality and to prepare successfully other people for it. One of the key subjects in preparing the future specialists in the field of the accounting is the financial accounting. Therefore, the quality training in that discipline is important for the entire professional development of the future accountant. In view of this, the aim of the present study is to analyze the applied methods in the modern training on financial accounting in European universities, selected on a reasonable sampling basis. The following research tasks have to be settled for reaching the above-mentioned goal: it has to be conducted an empirical study in European universities, selected on a reasoned sample basis, in which universities the financial accounting appears a discipline; there have to be studies the applied traditional and innovative methods in the training on financial accounting, as well as their proportion in the course of the teaching. Object of research shall be the scope of the training on financial accounting in the analyzed institutions; subject shall be the applied methods for training. In the course of the study shall be justified the thesis that the modern training on financial accounting appears a kind of synthesis between traditional methods and new digital tools (innovative methods).

\section{LITERATURE REVIEW}

The issues of the training on financial accounting and in particular the condition of the training process and the perspectives, which face it under the modern conditions of life and intensive challenges are addressed in the works of many authors (M. Pavlova, M. Musov, M. Dochev, R. Simeonova, R. Marinova, A. Atanasov, G. Chipriyanova, Denisa Mihaela Coman, Tadija Djukic, Mirjana Todorovic, Christian Favino, Francesco Contò, Bünyamin Bacak, etc.), they have been discussed within the frameworks of held scientific forums and meetings, but there is an entire complete scientific research on these issues. All ideas and conclusions in the developments are a good basis for implementation of the assigned tasks of the present research.

Together with the existing legal framework, including the Higher education act, Vocational education and training act, Ordinances, Implementing rules, Decrees of the Council of Ministers, a focus is made on the newest (up to date and adequate to the situation) legal requirements as the Ordinance on the state requirements for organizing a remote form of training in the higher institutions (НАРЕДБА за държавните изисквания за организиране на дистанционна форма на обучение във висшите училища, 2021), the Concept for digital transformation in education and with the prepared National program for Information and communication technologies-based innovative educational technologies and didactic models in the teaching practice. Furthermore, there are many requirements from the professional organizations and the business regarding level and quality of the training on financial accounting, professional experience in the course of 
the training process, knowledge, skills and competences.

The implementation of the research goals takes into account these restrictions and this basis are made proposals for systematization, optimization and improvement of the training process on financial accounting, being a synthesis between traditional methods and new digital tools, in accordance with the epidemiologic situation on a national level, in Europe and worldwide, the trends in the development of the business environment, the digital economy, the new payment ways, the new payment means etc.

\section{METHODOLOGY}

\subsection{Data}

\subsubsection{Data Acquisition}

The research addresses the organization, the methods and the good practices of the training on the subject „Financial accounting” at the universities in Europe of the students at Bachelor's degree. An empirical material was collected from the data base QS World University Rankings (QS World University Rankings 2021, 2021) of the presented 117 universities for Europe region for year 2021, subject Accounting and Finance, Bachelor's degree at departments "Economics" and "Administration and management" out of 300 universities as a whole. The choice of that base is driven by the circumstance that it is puts on a first place according to the number of visits from Alexa - the subsidiary of Amazon, which provides data about the web traffic, global rankings and other information for more than 30 million websites (Alexa - Competitive Analysis, Marketing Mix, and Website Traffic, 2021). The information about the research was taken from the official web sites of the universities.

\subsubsection{Data tidying and Cleaning}

The process on tidying and cleaning the data comprises selection of the universities under certain criteria. From the total number of 117 universities are excluded those, which offer training only in Master's or doctoral degree (26 universities), as well as the universities, which offer training in Bachelor's degree, but do not offer programs with courses in the field of the financial accounting (13 universities). One of the universities does not provide the needed information on its official web site and was excluded from the totality. So, the data base was reduced to 77 universities.

\subsubsection{Data Exploitation}

The distribution of the universities by countries shows the indisputable leadership of the United Kingdom, which is presented by 27 universities - more than one third of the total number. The next places are for the Netherlands, Italy and Spain, which participate respectively with 7,6 and 6 universities. The other European countries participate with 1 up to 4 universities (Fig.1).

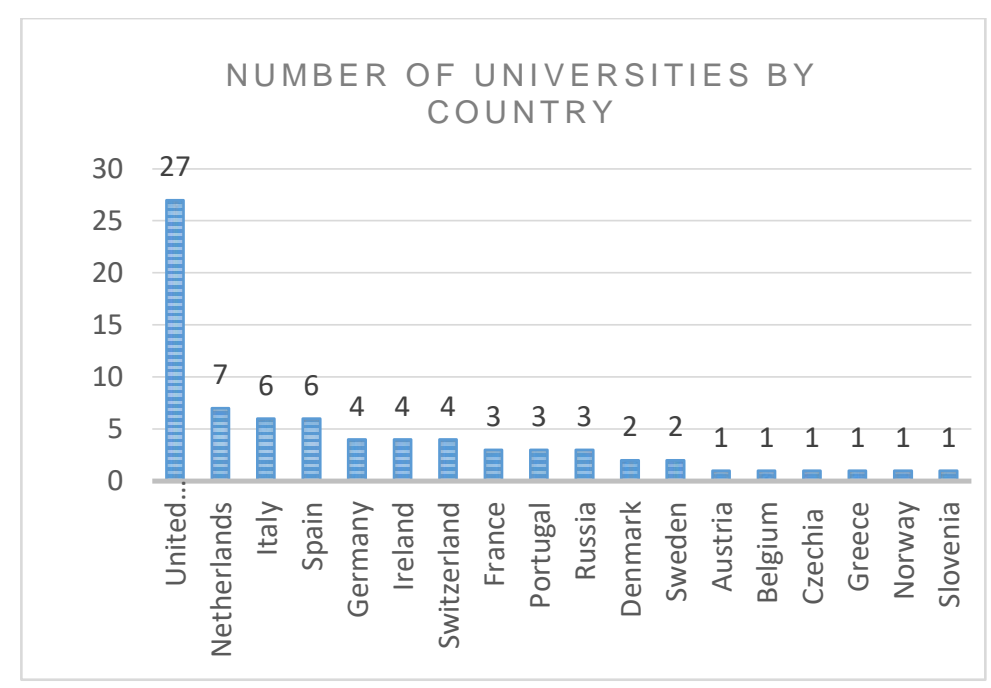

Fig. 1. Distribution of the universities by country

Research is made also with regard to the way of financing the higher institutions as it was established that from the total number of universities, 71 have funding from the state and the other 6 universities have private funding (Fig.2). 


\section{University funding status}

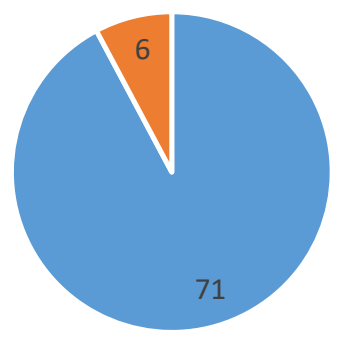

Fig. 2. Distribution of the universities by funding status

Within the frameworks of the research was made analysis of the titles of the subjects, which contain the problems in the financing accounting, as well as the year of their learning in the course of the educational degree. The results show that there is a great variety of subject titles, which have identical content. There were identified a total number of 105 subjects. The titles fall in groups, in three categories depending on the focus on the content, namely: Financial Accounting Group with 68 subjects, Financial Reporting Group with 24 subjects and Others Group with 13 subjects. Presentation of the results is in table 1.

Table 1. Title of the subjects in the field of the financial accounting by educational years

\begin{tabular}{|l|l|l|l|l|l|}
\hline Course name & Year 1 & Year 2 & Year 3 & $\begin{array}{l}\text { Year } \\
4\end{array}$ & $\begin{array}{l}\text { TOTAL } \\
\text { by } \\
\text { course }\end{array}$ \\
\hline FINANCIAL ACCOUNTING Group & 40 & 20 & 6 & 2 & 68 \\
\hline FINANCIAL REPORTING Group & 8 & 13 & 3 & 0 & 24 \\
\hline OTHERS Group & 8 & 5 & 0 & 0 & 13 \\
\hline TOTAL by years & 56 & 38 & 9 & 2 & 105 \\
\hline
\end{tabular}

The data allow making a cluster analysis of the distribution of the subjects from the three groups by educational years. The distribution of the subjects by educational years shows that in the most cases financial accounting is in curricula during the first and second year of the training in the respective Bachelor's degree, as mostly the title of the subject falls within the Financial Accounting Group. During the fourth educational year, training is offered only on two subjects from the same group - on Financial Accounting II at University College Dublin (Ireland) and on Advanced Financial Accounting at the University of Stirling (United Kingdom) (Fig. 3).

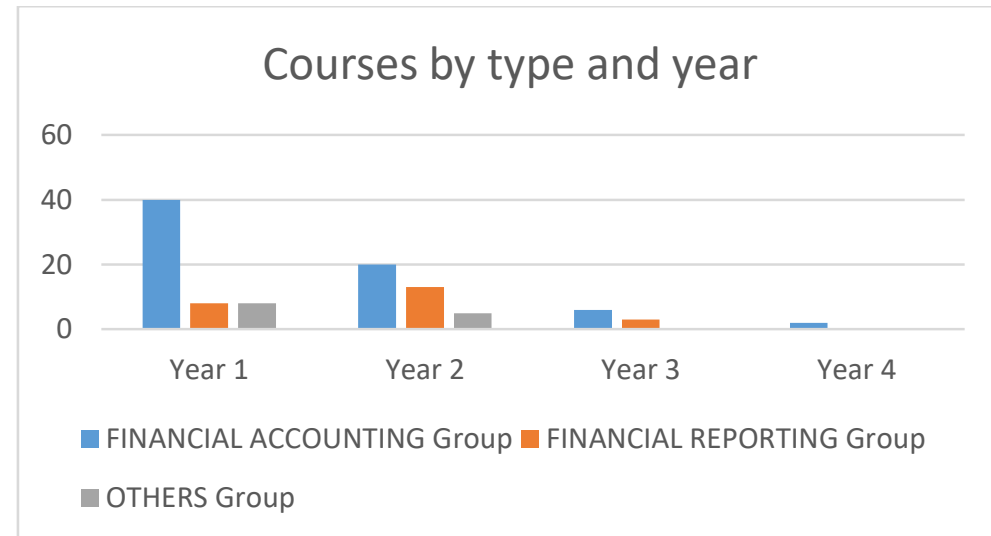

Fig. 3. Distribution of courses in the field of financial accounting by type and by year 
Another goal of the research is identification, classification and analysis of the training and evaluation methods in the database in two aspects - traditional and innovative methods. The result from systematization of the collected information is shown in table 2.

Table 2. Classification of the methods for training and evaluation

\begin{tabular}{|c|c|c|}
\hline & Traditional & Innovative \\
\hline Teaching methods & $\begin{array}{l}\text { Lectures/lecture materials, handouts, } \\
\text { slides; seminars; tutorials; analysis of } \\
\text { financial data and information }\end{array}$ & $\begin{array}{l}\text { Interactive lectures; webinars; interactive } \\
\text { discussions on discussion board or } \\
\text { private social media; animated slides and } \\
\text { didactic videos; computer-based } \\
\text { simulations; digital consultation (live } \\
\text { streamed) with chat function }\end{array}$ \\
\hline Learning methods & $\begin{array}{l}\text { Workshops; } \\
\text { individual/group; } \\
\text { demonstration; } \quad \text { work-based discussion; } \\
\text { placement learning; exercises; } \\
\text { projects; coursework; external visit; } \\
\text { mock audits }\end{array}$ & $\begin{array}{l}\text { Study cafes; exercises online; live chat; } \\
\text { online work in groups to prepare wikis; } \\
\text { computer labs; drop-in sessions }\end{array}$ \\
\hline $\begin{array}{l}\text { Exam/Assessment } \\
\text { methods }\end{array}$ & $\begin{array}{l}\text { Coursework; supervision; case studies } \\
\text { and analyses; written tests; student } \\
\text { tutorial portfolio; writing reports - } \\
\text { individual and group; essays; projects; } \\
\text { written exam; reflective portfolios }\end{array}$ & $\begin{array}{l}\text { Online quiz; online tests; online exam; } \\
\text { online diagnostic assessments; live } \\
\text { streamed exam; online automated } \\
\text { feedback; try-bonus-Test/Test (digital } \\
\text { keys some with feedback) }\end{array}$ \\
\hline
\end{tabular}

The data shows that the distribution of the methods of teaching, training and evaluation, applied in the researched universities, in the categories traditional and innovative is almost equal.

\subsection{Results}

\subsubsection{Data Analysis}

The results from the research of the European universities from the sample show that the training on financial accounting has a key role in the process of building the future specialists in the field of economics and management. Particularly active is the presence of this subject amongst the universities in the United Kingdom, which occupy more than one third of the total volume of the sample (35\%). Major prevalence has also higher institutions with state funding compared to the private ones - almost 12 times, as their share is $92 \%$ of the general totality.

The importance of the financial accounting for the students is proven also by the circumstance that the subject is learned mostly during the first and second year from the training process. The reason is that this subject comprises fundamental theoretical considerations and practical guidance, which appear basis for building specialists with high professional skills and competences for the labor market.

Of special interest is the systematization made of the methods for teaching, training and evaluation and their division to traditional and innovative. The results outline that all universities implement the classic lectures and a written exam. The diversity lies amongst the other elements of the methods, which provide the students, learning financial accounting, and it is as follows:

- The consistent awareness of the basic concepts, the theoretical and legal framework of the discipline by a set of traditional and innovative methods of teaching, as besides from the direct relation between trainees and trainers there are training materials also available;

- Opportunity for practical implementation of the acquired knowledge by group and individual work on projects, trainings, demonstrations through methods of learning, interesting and adequate to the modern requirements;

- Implementation of different forms for knowledge evaluation of, which develop skills for logical thinking through the classic written exam, skills for written expression by developing academic papers, organizational 
skills or team work in implementing projects etc.

What strikes is the balanced implementation from the universities of elements from the two categories of the methods - both traditional and innovative. Amongst the innovative ones, the major part concerns the modern conditions of technological invasion and digital transformation in the field of the higher education.

\subsubsection{Good Practices}

The process of the research work made possible the data mining for interesting, innovative and particularly up to date practices in the field of the training on financial accounting amongst the universities in focus. Some of these are as follows:

- Implementation of modern platforms of online training at the universities, which shows the high level of digitalization of the training process on financial accounting (for instance Toledo (KU Leuven, Belgium), StudyNet (University of St. Gallen (HSG), Switzerland), Canvas (Newcastle University, United Kingdom), Delphi on-line (University of Rome "Tor Vergata", Italy), SmartLMS (HSE University, Russia), Coniston (University of Birmingham, United Kingdom), WISEflow (Aarhus University, Denmark), Blackboard (The University of Sheffield, United Kingdom);

- Providing opportunity for the students for an individual training and performance by implementing the principles of the so called Flipped-Classroom concept (University of St. Gallen (HSG), Switzerland), private study hours (University of Leeds, United Kingdom), based on a 'real-life' pedagogy approach, using company data as well as articles from the business press (Stockholm School of Economics, Sweden), separate sessions led by a student mentor (Erasmus University Rotterdam, Netherlands) etc.;

- Providing opportunity for obtaining certificates from professional accounting organizations within the frameworks of the training in Bachelor's degree (from ACCA, ICAEW and CIMA (University of Bristol, Lancaster University, City, University of London, University of Leeds, Loughborough University, Aston University, University of Oxford, United Kingdom), from ICAS and CPA Australia (Lancaster University, United Kingdom), from CIPFA (Loughborough University, United Kingdom), from Institute for Accounting, Controlling and Auditing (University of St. Gallen (HSG), Switzerland);

- Implementing extra disciplines in the curricula, related to building soft skills, skills for employment and for continuous self-improvement (for instance IT lectures, Debate, Academic Writing, Accounting Careers paths, Presentation skills, Professional Skills);

- Ensuring an opportunity for training of foreign students for obtaining double diplomas and continuing education in Master's or doctoral degree.

\section{ISSUE DESCRIPTION}

It was established in an empirical way, that the training and teaching on financial accounting appears a totality of specific approaches, implemented in accordance with its contents and forms for organization of the learning process. Therefore, in that case the leading role is for the purposes and goals of the training, the particular approaches in clarifying certain curriculum (learning) content and the way of teaching of the individual methodical units, at which are used specific learning forms for reaching optimal results from the educational work. Three main tasks have to be solved in the course of training on financial accounting: the trainees have to obtain particular knowledge, which is mostly of theoretical nature, but has a serious practical weight; the trainees have to build logic, memory and associative thinking, which shall contribute for the proposed knowledge to be given meaning, to be understood and remembered permanently; the trainees have to establish specific practical skills, habits and competences, related to the future accounting work.

In the contemporary conditions the rational implementation of many traditional and innovative training methods, which are put under analysis in the present research may successfully solve the above-mentioned tasks

\subsection{Traditional Methods}

Traditionally in the theory and practice, the methods concern the ways and paths for reaching particular goals or solving particular tasks. As far as the issues of the training are concerned, the methods refer mostly to the approach of the lecturer in solving specific educational and training tasks. Hence the understanding that the methods describe the procedure part in the technology of the training.

It is important to outline that the training methods have a subjective nature too. This means that they shall depend on the nature of the professional training and the pedagogical skills of the lecturer himself. Moreover, 
the training methods determine the way of interaction between a lecturer and a student given the preliminarily set training goals. The dependence of the training methods from objective and subjective factors determines also their variety. This refers also to the training on financial accounting.

It is a fact that in the pedagogical practice and mostly in teaching economical subjects (incl. financial accounting) prevail the following traditional methods:

$\checkmark$ Presentation of the learning (educational) material - it is realized orally under the form of an academic lecture or a talk as a form of a dialogue (interactive) training method. Particularly in the case of the training on financial accounting are used variety of educational forms for presenting the contents of the subject. During the training, the lecturer explains and discusses the issues of financial accounting. Only good theoretical knowledge is not enough for the communication to be interesting and complete. There should exist knowledge also about the accounting practice, because describing practical cases significantly raises the interest of the students and makes the training much more effective. Each successful presentation of the learning materials is accompanied by: careful consideration of the logical succession and preparation of a plan for the presentation; appropriate choice of examples from the practice; observance of the legal framework; choice of an appropriate way for illustration of the educational content; maintaining an adequate emotional tonus in the students.

$\checkmark$ Demonstration with pictorial training aids - it may be realized both during presentation of the educational content and during activities in a specially equipped accounting workroom or in a specific enterprise. The choice of a proper combination in the particular case depends on many factors as the set educational goals (tasks); the contents and connections of the methodical unit or topic; the nature of the graphic means; the level of training of the students; etc. The contents of the educational material on financial accounting assumes a high extent of synchronization between the pictorial and oral methods. The aim is to be involved to a maximum extent the attention of the students incl. the opportunity of discussions and conclusions.

$\sqrt{ }$ Written and graphic exercises - they are used in a proper combination with the oral and the graphic methods, because their practical realization is always connected with the respective basic learning theories. Generally, the accounting subjects are of theoretical applied nature. As a part of the curricula are the lectures for obtaining new knowledge and seminar activities (exercises) for assimilation and deepening of the acquired knowledge from the students. As far as the seminar activities on financial accounting are concerned, they should have a clearly stated goal, to have degrees of difficultness, to be in a logical succession according to the presentation of the learning material, to raise the students' motivation. It is recommended the results from each exercise to be analyzed.

$\sqrt{ }$ Training in the practice - the practical focus of the training on financial accounting causes its maximum closeness to the accounting practice. The aim is the students to get involved in the accounting practice regularly in order to feel the professional relations, to get the rhythm of the accounting work. In case of an impossibility for such real trainings it is possible the implementation of some simulation-based training methods for financial accounting, for example - the "game method" (referred also as „a role-playing game“).

$\checkmark$ Students' self-study process - both within the universities and at home. This work may be of various nature, but it is important to be established proper conditions about its complete and effective realization.

$\checkmark$ Visit in the practice (accounting departments, accounting and audit enterprises, etc.) - the implementation of that method needs a preliminary preparation and organization in relation to the conduction of meetings with leading accounting specialists and auditors with established practical experience. The aim is by these meetings the students to get direct up to date information, connected with the accounting and auditing practice.

$\sqrt{ }$ Examination and evaluation of the knowledge and skills of the students - the examination and evaluation of the knowledge and skills of the students is a form of control, which has a pointedly diagnostic value but the examination and the results are also a training method, because in the process of their use is acquired new knowledge too. The examination and evaluation of the knowledge and skills of the students on financial accounting may be realized face-to-face, in written or in a combined way. From methodical point of view, the forms for the examination and evaluation of the knowledge and skills, used in the training, should be combined. By combining one can get more various impressions from the whole training of the student and the evaluation itself is objective and fair, which is also the final goal, resulting from the implementation of the method.

\subsection{Digital Tools}

The pandemic, economic turbulence, social isolation, mass digitalization of the communications, 
virtualization of all forms of communication during the last years accelerated the processes on implementation of innovative methods for training on financial accounting in the universities. A research was made by the help of the structured interview methodology amongst universities in Europe with a Department of Economics, at which is learned the subject „Financial accounting“ by the method of random non-recurrent selection (Bulgaria, Romania, Serbia, Italy, Poland, Croatia, Lithuania and Slovakia). The research refers to the attitudes to the traditional methods, the innovative methods, the digital instruments, the types of methods, which are successfully implemented, the extent of integration of the innovative methods in the training process, etc. The starting prerequisite of the research is that in the last years the innovative methods are prevailing over the traditional forms and techniques of the training process on financial accounting. The COVID-19 pandemic made the universities react in short terms regarding the implementation of alternative approach to the educational process under extraordinary circumstances. The received results for the sample could be visualized in the following way (Fig. 4):

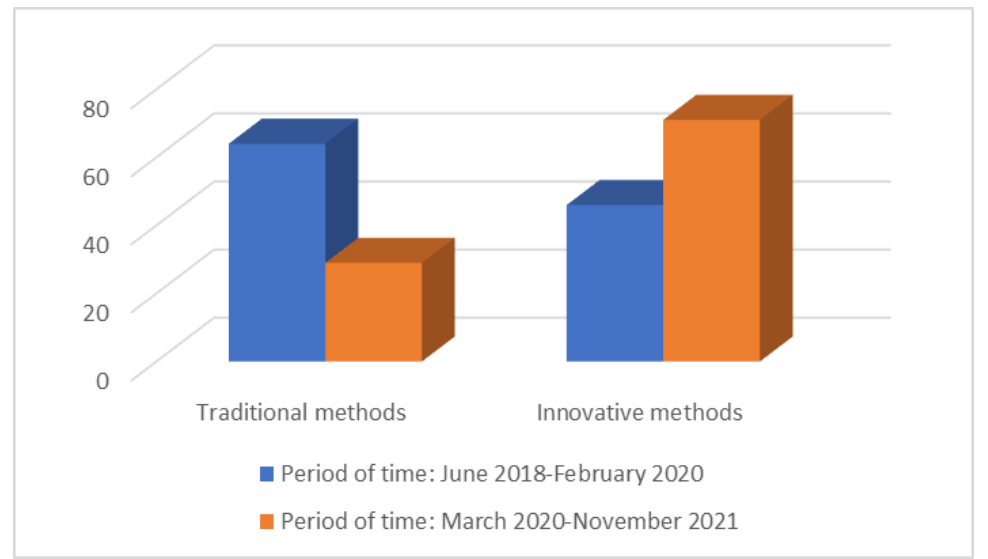

Fig. 4. Extent of use of the traditional and innovative methods in the course of the training on financial accounting in rates (June 2018-February 2020; March 2020-November 2021)

The results from the held interview prove that the prevailing attitudes tend to raise the share of the innovative methods, as compared to the traditional methods. Underlying appears the provision of a free access of the students to the training process under extraordinary circumstances. The respondents treat the innovative methods as a wide selection of software solutions, as a major part of them appear tools of the training and in particular the relation between the lecturer and the students. They also contribute to the synchronous and asynchronous communication between the two parties in the training process and another part are associated with a specialized program product, used in the hours on financial accounting. In particular, for educational purposes are used demo versions of a widely implemented accounting software.

The respondents have stated the following types of innovative methods, which are successfully implemented under the conditions of internet based information and communication technologies (remote education platform, social networks and sites for communication and training) in the course of the training process on financial accounting in the period of pandemic: interactive training (72,2\%), incidental training (47,3\%), problem-oriented training $(49,9 \%)$, case training $(97,8 \%)$, role and game type of training $(66,1 \%)$, cooperative/joint training $(87,8 \%)$. The received results exceed $100 \%$, because the respondents had the right to state more than one answer.

The results from the research support the thesis that the digital instruments being a part of the innovative methods, implemented in the training process on financial accounting at the universities in Europe with a Department of Economics, meet the need to make learning accessible and the students- active and responsible to the process of their own training. In the last 1-2 years, the digital instruments, implemented for the training on financial accounting, are creating the necessary conditions for development of the students' potential, their inner confidence and independence. The positive result is that they have higher personal responsibility for their decisions and actions, as well as for the effects of that. $92.6 \%$ of the respondents answer that the digital instruments create an environment for work on financial accounting, which encourages the students and their lecturers to be creative and innovative by thinking about how to learn and implement the knowledge in a long-term plan. This supports the successful realization of the current concept about the university training, based on competences.

More than $70 \%$ of the respondents think that in the last 1-2 years the digitalization of the processed related to the training on financial accounting, creates many new opportunities and results in the occurrence of new 
competitive challenges. The results from the sample show that a leading commitment in the digitalization is the inclusion of digital technologies in the process, existing so far, for realization of gradation in the activity by use of digital data, adding more value for the users of the educational product (virtual auditoria, multimedia lectures, lectures on financial accounting, innovative lessons, digital textbooks and training aids, research training etc.)

The digital transformation should be treated as a change with a set of intermediate targets, related to continuous optimization of the processes, units and subsystems through building proper bridges (between the entry and exit points of the systems, data, solutions, people, teams, technologies, different participants and etc.), which are of significant importance for reaching the final success. The human factor is a key factor at all levels or stages of the digital transformation (Орехов, н.д.).

The analysis of the external factors, influencing the training process on financial accounting and the analysis of the internal factors of direct importance for the success of the digitalization of the training on financial accounting are important for the research. The external factors relate mostly to the up to date trends and changes in the social-economic life. Key internal factors are strong leadership, strategic goals of the digitalization, establishment of new working models, finding proper digital tools. The respondents have stated the following factors, affecting the process of digitalization of the training on financial accounting before the pandemic and in the last 1-2 years: adaptive learning technology is useful for retaining interest in learning financial accounting (ALT), students are more involved when they have digital material for the course "Financial accounting" (DM "FA"), digital learning improves students' knowledge of financial accounting (DLknowledge), digital learning encourages students to be active and responsible in the process of their own learning in financial accounting (DL-active/responsible), students are positive about online forms of testing and self-preparation, adaptive learning in financial accounting and e-textbooks (Online forms of TSP), students have the opportunity to learn by actively using a personal mobile electronic device (PMED), in addition to everything else, digital learning helps students to improve their computer skills, math and other technical skills (DL-CSMTS). The results could be visualized in the following way (Fig. 5):

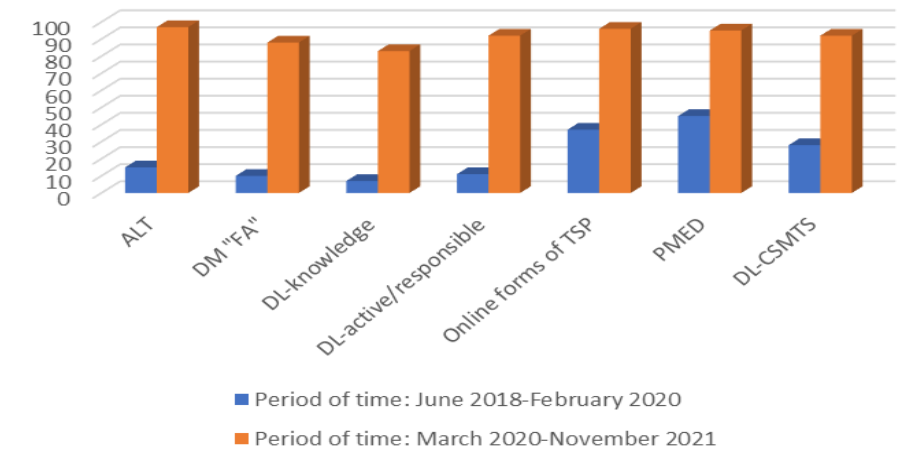

Fig. 5. Factors, of which depends the process of digitalization of the training on financial accounting before the pandemic and in the last 1-2 years in rates.

Further, by the synthesis method the received results create three particular directions for digitalization of the training on financial accounting with regard to the training of the future specialists on financial accounting under the current conditions and within the frameworks of the modern information worlds, as follows:

$\checkmark$ Traditional training on financial accounting with elements of electronic training (traditional training, combined with elements of connectivism) (Siemens, 2005) - it is characterized by a wide selection of information and communication technologies in the traditional training process on financial accounting. The traditional methods and the digital instruments may participate in various full of matter and organizational relations. Thus, the digital technologies may be successfully implemented both in teaching and learning the subjects and in the pedagogic interaction between the lecturer and the student. The goal is to preserve the positives of the already proven scheme of classic teaching by upgrading with some digital elements. This way the process of training on financial accounting of the future specialists shall become more flexible and shall have deeper content.

$\checkmark$ Synchronous remote training on financial accounting - the student interacts in real time with his costudents and with the lecturer. The advantage of this variant is that the feedback is direct and is realized simultaneously. The idea is the attention and the efforts to be put on tools, operating in real time (systems for videoconference connection and virtual classrooms, web conferences, chat rooms, audio podcasts etc.), 
which to contribute to the interaction between lecturers and the students at the same moment.

$\checkmark$ Asynchronous remote training on financial accounting - it is preferably to organize for these stages and periods of work, when the lecturers and the students are offline. The students do not interact directly with the lecturer as well as with the other students; the student alone determines his work rhythm. The strong points of this variant are related to the opportunity for: lectures, published in internet environment, multimedia educational aids and virtual libraries, emails and messages, „Google Drive“ (Ресурси, платформи и добри практики за дистанционно обучение, n.d.), forums, cloud technologies (Cloud) and other.

$99,5 \%$ of the respondents share that there are almost no defects, because the individual variants complement each other, they do not exclude each other. A key factor in the three variants for conduction of the training on financial accounting with digital tools is the interaction between the participants in the learning process. In this context N. Campbell states that the various forms of training and their combination using innovative tools and internet connection are not just access to some information or even more access to information and communication technologies; there must be activity between the participants - both traditional and innovative training (Campbell, 2001).

Based on the research, made amongst universities in Europe with a Department of Economics, at which is learned the subject "Financial accounting" by the method of random non-recurrent selection (Bulgaria, Romania, Serbia, Italy, Poland, Croatia, Lithuania, Slovakia) it may be drawn the conclusion that the expectations are the digital training on financial accounting shall prepare the students for the age of the digital transformation, future of accounting, virtual (cloud) accounting and for their successful professional realization as accountants of the future.

\section{DISCUSSION AND CONCLUSION}

The empirical research, realized in the universities from the target group confirms that the training on financial accounting is a key factor for the students on economy and management.

The importance of the training on financial accounting for the students is proven also by the circumstance that the subject is learned with priority during the first and second year of the training. The reason is that it comprises both fundamental theoretical knowledge and practical aspects, which are basis for building specialists with high professional skills and competences on the labor market.

Of particular interest is the systematization, made of the teaching methods, training and evaluation of traditional and innovative, as it strikes their balanced implementation by the universities under research.

From the above-stated far now, the reasoned conclusion that the totality of methods falls within the prerogatives and is constituted by the lecturer in accordance with the established educational goal.

In fact, the methods always combine, penetrate into each other and complement each other, characterizing from different aspects the main goal, namely - the effective interaction between a lecturer and a student. That is why, when under certain conditions the implementation of particular method prevails that means that it is the most appropriate for solving the assigned educational task. Possible change of the situation, respectively of the task, causes of course an adequate change in implementing the respective methods. The leading motive in this case is that if the choice of educational methods lies on more aspects, the educational results, reached in the training, shall be more thorough and lasting.

From methodological point of view, the combination of the different methods (traditional and innovative) in the process of the training on financial accounting should have as a leading start the following: correspondence between the methods, principles, goals and tasks of the training; correspondence with the capabilities of the students (capabilities of the age, psychical, educational, moral ones); correspondence with the nature of the educational content; correspondence with the conditions and the stage of the training; correspondence with the professional and personal features of the lecturers.

Therefore, these are all factors that reasonably define as prerequisites for the proper choice of method or totality of training methods in teaching financial accounting.

In conclusion, the wider implementation of digital technologies and tools in the process of training on financial accounting is very important for ensuring accessibility, actuality and management of the resources as a basis for a quality education. For reaching that goal, the users in the educational process have a universal electronic access to embedded platforms for educational services and specialized content.

As a result of the realized scientific research it can be made a reasoned summary that the rational organization of the training process on financial accounting should be based on reasonable (optimal) 
proportions between traditional methods and innovative methods (digital tools) for acquiring lasting knowledge, skills and competences for the business.

\section{REFERENCE LIST}

Alexa - Competitive Analysis, Marketing Mix, and Website Traffic. (2021, December 03). Retrieved from https://www.alexa.com/siteinfo: https://www.alexa.com/siteinfo

Campbell, N. (2001). E-teaching and its Impact on Teachers. In Issues in Online Learning Reader, 2001. Retrieved from https://www-it.fmi.uni-sofia.bg/courses/elearning/OsnovniVuprosi/iztochnici.html

QS World University Rankings 2021. (2021, December 03). Retrieved from https://www.topuniversities.com/university-rankings/world-university-rankings/2021: https://www.topuniversities.com/university-rankings/world-university-rankings/2021

Siemens, G. (2005, January). Connectivism: A learning Theory for the Digital Age, International Journal of instructional technology \& distance learning, January 2005, Vol. 2, № 1. Retrieved from http://www.itdl.org/Journal/Jan_05/article01.htm: http://www.itdl.org/Journal/Jan_05/article01.htm

НАРЕДБА за държавните изисквания за организиране на дистанционна форма на обучение във висшите училища. (n.d.). В сила от 01.09.2021 г. Приета с ПМС № 78 om 05.03.2021 2. Обн. ДВ. бр.21 от 12 март 2021 г.; https://www.mon.bg.

Орехов, М. (n.d.). Същност на процеса на дигитализация като нов етап в глобалната трансформация. Retrieved from https://dlib.unisvishtov.bg/bitstream/handle/10610/4232/b3de375611d0a9221dae05beb7bae8c0.pdf? sequence $=1$ \&isAllowed $=\mathrm{y}$

Ресурси, платформи и добри практики за дистанционно обучение. (n.d.). Retrieved from https://zaednovchas.bg/distancionno-obuchenie/: https://zaednovchas.bg/distancionno-obuchenie/ 